\title{
FACTORS RELATED TO SMALL SCALE CATTLE FATTENING IN RURAL AREAS OF BANGLADESH
}

\author{
T. Ahmed ${ }^{1}$, M. A. Hashem ${ }^{1}$, M. Khan ${ }^{1}$, M. F. Rahman ${ }^{2}$ and M. M. Hossain ${ }^{1}$
}

\begin{abstract}
The experiment was conducted to investigate the systems of management in small scale cattle fattening programs. The data were collected through an interview schedule from 215 respondents of 24 districts in 52 upazilla who were involved in small scale cattle fattening. In this study out of 215 respondents $70.4 \%$ were farmers, $11.7 \%$ businessman, 9.18\% physicians, $2.04 \%$ doctors had own land and $8.8 \%$ respondents had no own land. About $40.9 \%$ respondents selected cattle on the basis of age and 14, 25.6 and $16.7 \%$ respondents selected on the basis of breed, age and sex, respectively. Most of the respondents (79.1\%) fattened cattle for 3-6 months and rest fattened for a prolonged period. About 90.2\% respondents used own capital for cattle fattening and 2.3, 4.2 and $3.3 \%$ respondents took bank loan, NGO loan and lending for cattle fattening, respectively. About 31.6\% respondents provided existing traditional cattle shed. About $79.5 \%$ did not have any training on cattle fattening whereas about $20.5 \%$ respondents had taken short training on cattle fattening. About $63.7 \%$ respondents used cattle fattening tablets, $27 \%$ respondents used urea molasses straw (UMS) and $51 \%$ followed conventional feeding. About $72.6 \%$ vaccinate the cattle by themselves and about $76.3 \%$ took help from veterinary surgeon for treatment of their cattle. About $45 \%$ reported shortages of animal feed, 50\% reported lack of credit and 95\% reported high cost of feed as the major problems of small scale cattle fattening. The results of this study will be useful for farmers and researchers to identify the overall problems and their remedies on feeding, management and marketing related to small scale cattle fattening practices in Bangladesh.
\end{abstract}

Key words: Cattle fattening, Factors, Beef production, Bangladesh

\section{Introduction}

Cattle of Bangladesh are an inseparable and integral part of the agricultural farming and agribusiness system. Beef fattening is an emerging sector for employment and income generation for the rural poor, especially landless, destitute and divorced women. Cattle fattening is an effective tool for poverty alleviation for the rural poor. Cattle fattening for beef production has become an important business of the small farmers in Bangladesh. One of the advantages of the cattle fattening by the rural farmers is that they use locally available cattle feed resources during the Eid festival. In recent years the women farmers of

\footnotetext{
${ }^{1}$ Department of animal science, Bangladesh Agricultural University, Mymensingh-2202, Bangladesh

${ }^{2}$ ACI Ltd. Dhaka, Bangladesh
}

(Received: August 11, 2010) 
Bang. J. Anim. Sci. 2010, 39(1\&2)

Bangladesh have been involved and sustained beef fattening program in rural areas of the country. The information available in the literature on cattle fattening by small farmers in rural areas are few and sporadic (Hossain, 1986; Hossain et al., 1996a; Huq et al., 1997 and Hashem et al., 1999). To develop a sustainable beef cattle production system in Bangladesh which starts at the farmers' level for production and ending at consumers' level for consumption, it is necessary to find out the existing beef cattle production, marketing, processing systems and consumers' perceptions. For this it is prime important to find out the existing cattle fattening system and those factors which are directly related with cattle in Bangladesh. Therefore, the present study was undertaken with the following objectives: (i) to investigate the feeding, management and marketing system of small scale cattle fattening. (ii) to identify the problems related to cattle fattening program and their potential solutions.

\section{Methodology}

The present study was conducted to investigate the cattle fattening program practiced by the rural farmers in different districts of Bangladesh. The data was collected through an interview schedule involving 215 respondents of 24 districts in 52 upazilla who were involved in cattle fattening before Eid-ul-Azha (December, 2008). The respondents were selected who rear cattle or bought cattle for fattening. Respondents were randomly chosen from each upazilla. In total 215 respondents were chosen for collecting data to address the objectives. The interview schedule was prepared based on the objectives of the study. In this study 215 respondents were interviewed to find out the socio economic condition of them. The selected characteristics included age, family size, land size and occupation. The age of the respondents ranged from 20 to 70 years. The respondents were grouped into three categories, young age (up to 35 years), middle age (36 to 50 years) and old age (above 50 years). Family size of the respondents ranged from 2 to 13 members. The family sizes of the respondents were classified into three categories. These were small (2-3 members), medium (4-6 members) and large (above 6 members).

Data were collected following the direct interviews and making frequent personal visits. Interviews were normally conducted in the market or in respondent's house during their leisure time. Secondary data were collected from BBS, journals, reports and various published articles. The interview schedule contained the following items of information. General information of the cattle fattening owners, livestock population, management of the fattening cattle, feeds and feeding cattle, indigenous knowledge on rearing cattle and marketing of cattle. The problems and probable solutions related to small scale cattle fattening were also identified.

The collected data were analyzed statistically by using simple statistical tools like average and Per centages as well as Chi-square through SPSS software. 
Small scale cattle fattening

\section{Results and Discussion}

\section{Socio-economic background}

Number and Per centage distribution of respondents according to their age group, family size and occupation are shown in Table 1.

Table 1. Distribution of respondents according to their age, family size and occupation

\begin{tabular}{|l|l|c|c|}
\hline \multicolumn{1}{|c|}{ Parameters } & \multicolumn{1}{c|}{ Categories } & $\begin{array}{c}\text { Number of } \\
\text { respondents }\end{array}$ & $\begin{array}{c}\text { Per cent of total } \\
\text { respondents }\end{array}$ \\
\hline \multirow{2}{*}{ Age } & Young age (up to 35 years) & 48 & 22.3 \\
& Middle age (36 to 50 years) & 108 & 50.2 \\
& Old age (above 50 years) & 59 & 24.4 \\
\hline Family size & Small family (2-3 members) & 1 & 0.5 \\
& Medium family (4-6 members) & 85 & 39.5 \\
& Large family (above 6 members) & 129 & 60.0 \\
\hline \multirow{2}{*}{ Occupation } & Farmer & 151 & 70.2 \\
& Business & 24 & 11.2 \\
& Shop keeper & 1 & 0.5 \\
& Teacher & 18 & 8.4 \\
& Service & 14 & 6.5 \\
& Doctor & 7 & 3.3 \\
\hline
\end{tabular}

It is revealed that the majority (50.2\%) of the respondents were in the middle age category, $22.3 \%$ and $24.4 \%$ of the respondents were in the young and old aged, respectively. In case of family size, $60.0 \%$ of the respondents belong to large sized family which was also a representative of typical family size of Bangladesh. Out of the 215 respondents $70.2 \%$ are involved in agriculture, $11.2 \%$ in business, $8.4 \%$ in Teacher, $6.5 \%$ in service and $3.3 \%$ in doctor. The total respondents were classified into six categories.

Number and Per centage distribution of respondents according to the land size are shown in Table 2. Land size was categories on the basis of the respondents' occupation. The major category $(70.4 \%)$ of the respondents belongs to farmer categories which had own land and $11.7 \%$ businessman, $9.18 \%$ Teacher, $6.63 \%$ service holder and $2.04 \%$ doctor had own land. In total 91.2\% respondents had own land and 8.8 had no own land. Distribution of respondents according to their own land differs significantly $(\mathrm{P}<0.01)$. Almost all the respondents reported that one or more of their family member were involved in beef cattle rearing program. Not a single respondent is reported to hired labour for this purpose. The result of this study differed from Hossain et al. (2002) where he found that the average age of the farmers range from 27 to 40 years and they had a minimum land for cultivation, whereas 
Bang. J. Anim. Sci. 2010, 39(1\&2)

in this study the average age of the respondents ranged from 20 to 70 years and $91.2 \%$ respondents had a minimum land for cultivation.

Table 2. Distribution of respondents according to their land size

\begin{tabular}{|l|c|c|}
\hline \multirow{2}{*}{ Categories (Occupation) } & \multicolumn{2}{|c|}{ Own land } \\
\cline { 2 - 3 } & Yes (\%) & No (\%) \\
\hline Farmer & $138(70.4)$ & $13(68.4)$ \\
Business & $23(11.7)$ & $1(5.26)$ \\
Shop keeper & 0 & $1(5.26)$ \\
Teacher & $18(9.18)$ & 0 \\
Service & $13(6.63)$ & $1(5.26)$ \\
Doctor & $4(2.04)$ & $3(15.7)$ \\
\hline Total & $\mathbf{1 9 6}$ & $\mathbf{1 9}$ \\
\hline Per cent & $\mathbf{9 1 . 2}$ & $\mathbf{8 . 8}$ \\
\hline
\end{tabular}

Chi-square test $(\mathrm{P}<0.01)$

\section{Factors associated with cattle fattening}

Factors associated with cattle fattening by the respondents are shown in Table 3. About $40.9 \%$ respondents selected their cattle on the basis of age and 14, 25.6 and $16.7 \%$ respondents selected their cattle on the basis of sex, breed (indigenous or crossbred) and age \& sex respectively. Most of the respondents fattened cattle for 3-6 months (79.1\%) and rest fattened a prolonged period. About $90.2 \%$ respondents used own capital for cattle fattening and 2.3, 4.2 and 3.3\% respondents took bank loan, NGO loan and lending for cattle fattening. About $31.6 \%$ respondents provided existing traditional cattle shed. About $79.5 \%$ respondents did not have any training on cattle fattening whereas about $20.5 \%$ respondents had taken short training on cattle fattening. About $63.7 \%$ respondents used cattle fattening tablets, $27 \%$ respondents fed UMS and 51\% respondents used none of these in cattle fattening. About $72.6 \%$ respondents used vaccine against infectious disease regularly for their cattle and about $76.3 \%$ respondents took help from veterinary surgeon for treatment of their cattle.

Table 3 showed that $90.2 \%$ respondents used own capital for small scale cattle fattening and $72.6 \%$ respondents used vaccination for fattening programme. The result of this study was in agreement with Begum et al. (2007) where they reported that $86.7 \%$ farmers used own capital and $83.3 \%$ farmers used vaccination for cattle fattening. In this study about $79.1 \%$ respondents found that the fattening period of cattle suitable was 3-6 months before Eid-ulAzha. While working with the farmers in rural areas of Bangladesh, Hossain (1986) and Hossain et al. (1996a) reported cattle fattening periods of 4-5 months and 5.7 months, respectively. In this study most of the respondents (68.4\%) kept their animals in shed built for a batch, whereas the rest $31.6 \%$ respondents kept in existing traditional cattle shed. The result of this study was in agreement with Hossain et al. (1996a) where they reported that majority of the farmers kept cattle in separate houses for fattening purposes. Important 
factors involved in small scale cattle fattening are capital, feeds and fodder, grazing land, availability of cattle and their marketing, labor and labor management, health care and treatment, training on cattle fattening and location of market found in this study.

Table 3. Factors associated with cattle fattening

\begin{tabular}{|c|c|c|c|}
\hline Parameters & Categories & $\begin{array}{c}\text { Numbers of } \\
\text { respondents }(n=215)\end{array}$ & $\begin{array}{c}\text { Per cent of total } \\
\text { respondents }(n=215)\end{array}$ \\
\hline \multirow[t]{5}{*}{ Cattle selection } & Age & 88 & 40.9 \\
\hline & Sex & 30 & 14.0 \\
\hline & Breed & 55 & 25.6 \\
\hline & Age \& Sex & 36 & 16.7 \\
\hline & Other & 6 & 2.8 \\
\hline \multirow[t]{3}{*}{ Fattening period } & $<$ Upto 6 months & 170 & 79.1 \\
\hline & 6-12 months & 10 & 4.7 \\
\hline & >Above 12 months & 35 & 16.3 \\
\hline \multirow[t]{4}{*}{ Source of money } & Bank loan & 5 & 2.3 \\
\hline & Own capital & 194 & 90.2 \\
\hline & NGO loan & 9 & 4.2 \\
\hline & Lending & 7 & 3.3 \\
\hline \multirow[t]{2}{*}{ Cattle housing } & $\begin{array}{l}\text { Existing traditional } \\
\text { cattle shed }\end{array}$ & 68 & 31.6 \\
\hline & Shed built for a batch & 147 & 68.4 \\
\hline \multirow{2}{*}{$\begin{array}{l}\text { Training on cattle } \\
\text { fattening }\end{array}$} & Taken & 44 & 20.5 \\
\hline & Non taken & 171 & 79.5 \\
\hline \multirow{3}{*}{$\begin{array}{l}\text { Technology used for } \\
\text { fattening }\end{array}$} & UMS & 27 & 12.6 \\
\hline & Cattle fattening tablets & 137 & 63.7 \\
\hline & No technology at all & 51 & 23.7 \\
\hline \multirow[t]{2}{*}{ Govt. office support } & Yes & 38 & 17.7 \\
\hline & No & 177 & 82.3 \\
\hline \multirow[t]{2}{*}{ Vaccination } & Regularly & 156 & 72.6 \\
\hline & Irregularly & 59 & 27.4 \\
\hline \multirow[t]{2}{*}{ Treatment of cattle } & By veterinary surgeon & 164 & 76.3 \\
\hline & $\begin{array}{l}\text { By quack (Unskilled } \\
\text { village doctor) }\end{array}$ & 51 & 23.7 \\
\hline
\end{tabular}

\section{Feeding system in cattle fattening}

Both extensive and semi-intensive production systems were practiced reported by the respondents for cattle fattening. Extensive system consisted of grazing their own croplands 
Bang. J. Anim. Sci. 2010, 39(1\&2)

after harvesting crops and grazing on roadside grasslands. Semi-intensive system included cut and carry and stall-feeding system. During rainy season (March to August) rice straw, green grass, mustard oil cake, wheat bran, rice polish and molasses on the other hand during dry season (September to February) rice straw, green grass, mustard oil cake, wheat bran, rice polish, molasses, water hyacinth, tree leaves, weeds and kitchen waste were used by the respondents.

Rice straw was the main feed source in the study areas. In all the upazillas under study most of the respondents compulsorily bought rice straw as their cattle feeds. Chopped rice straw was offered mainly during stall-feeding with adequate supply of water. Respondents used ponds, wells, tube-wells as the source of water for their cattle. Traditional feed and water troughs were used for these purposes. Many respondents had knowledge on some of the feeding technologies and high quality fodder cultivation. In the study area the respondents found using Urea Molasses Straw (UMS) technology to fatten their cattle which was only $12.7 \%$ of the total respondents under study. None of them was found to cultivate fodder crops for this business owing to lack of own land. Distribution of respondents according to their feed availability for small scale cattle fattening differs significantly $(\mathrm{P}<0.01)$. Out of the 215 respondents, $47 \%$ respondents said that feeds were available but $53 \%$ respondents said that feeds were not available (Table 4).

From this study 53\% respondents reported that feeds are not available for small scale cattle fattening. The result of this study was in agreement with Rahman et al. (2001) where 70\% respondents reported that feeds are not available. One of the advantages of the small scale cattle fattening by the rural respondents is that they used locally available feed resources. No improved feeding technologies, such as urea treated straw and Urea Molasses Block supplements were used by the farmers. Although they were trained but they did not follow this technology because they seemed that it was difficult and time consuming. Indigenous knowledge on cattle feeding like chopping of straw, mixing of green grass with straw, feeding tree leaves etc (Rahman et al., 1998) practiced by the rural farmers of Mymensingh was more or less same to the feeding practices of the present study.

\section{Marketing system of beef cattle}

The channels of beef cattle marketing found in the study areas are shown in Figure 1. Before the festival of Eid-ul-Azha, animals are taken to local market for selling, on market days (Hut). Buying and selling are completed through bargaining practice. In the process of cattle marketing middlemen and butchers are involved.

It is the pipe line through which a product flows on its way to the consumers which is in agreement with Rashid (1969). He said that marketing channel referred to the sequential arrangement of various marketing intermediaries involved in the movement of products from production to consumers. In this study area intermediaries were involved in marketing cattle. 
Table 4. Distribution of respondents according to the availability of feed for cattle fattening

\begin{tabular}{|c|c|c|c|}
\hline & \multirow[t]{2}{*}{ Occupation } & \multicolumn{2}{|c|}{ Does feeds are available } \\
\hline & & Yes (\%) & No (\%) \\
\hline & Farmer & 67 (66.3) & $84(73.7)$ \\
\hline & Business & $21(20.8)$ & $3(2.63)$ \\
\hline & Shop keeper & $1(0.99)$ & 0 \\
\hline & Teacher & 8 (7.92) & 10 (8.77) \\
\hline & Service & $3(2.97)$ & $11(9.64)$ \\
\hline & Doctor & $1(0.99)$ & $6(5.26)$ \\
\hline Total & & 101 & 114 \\
\hline Per cent & & 47.0 & 53.0 \\
\hline
\end{tabular}

Chi-square test $(\mathrm{P}<0.01)$

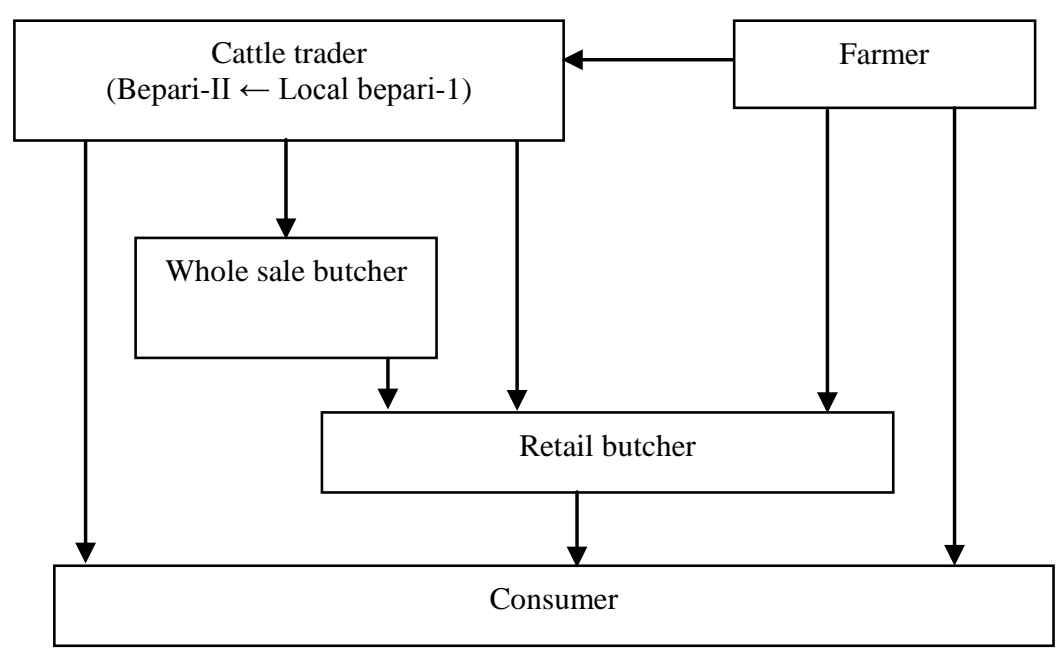

Fig. 1. Marketing channel of beef cattle in Bangladesh

\section{Problems and suggestions on fattening and marketing of cattle}

Table 5 shows that 95\% respondents mentioned that high price of the cattle feeds is the greatest problem for small scale cattle fattening. The result of this study differed from Ali and Anwar (1987) where they found that shortage of animal feed was the greatest problem of the farmers for rearing cattle. Hashem et al. (1999) reported that lack of training, lack of credit facilities, price variation in different markets, disorganized marketing system were the problem for cattle fattening in Bangladesh. They also mentioned that about $98 \%$ farmers had the problem of transporting cattle for marketing. The result of this study was more or less similar to Hashem et al. (1999). 
Bang. J. Anim. Sci. 2010, 39(1\&2)

Table 5. Problems on fattening and marketing of cattle

\begin{tabular}{|c|c|}
\hline $\begin{array}{l}\text { Problems and Per cent of total respondents } \\
(n=215)\end{array}$ & $\begin{array}{l}\text { Suggestions and Per cent of total respondents } \\
(n=215)\end{array}$ \\
\hline $\begin{array}{l}\text { Fattening aspect: } \\
\text { 1. High price of feeds (95) } \\
\text { 2. Lack of knowledge about fattening (90) } \\
\text { 3. Lack of cattle shed (85) } \\
\text { 4. Low capital investment (50) } \\
\text { 5. Shortage of cattle feed (45) } \\
\text { 6. Lack of sufficient green grass supply (40) } \\
\text { Marketing aspect: } \\
\text { 1. Unhygenic condition of market place (95) } \\
\text { 2. Lack of place in the market (85) } \\
\text { 3. No market rules and regulation (80) } \\
\text { 4. Price fluctuation (75) } \\
\text { 5. No grading system of cattle (73) } \\
\text { 6. Higher transportation cost (71) } \\
\text { 7. Unfair price from dalal (65) }\end{array}$ & $\begin{array}{l}\text { Fattening aspect: } \\
\text { 1. Lowering the feed cost (85) } \\
\text { 2. Need government support (70) } \\
\text { 3. Training facilities to the people (70) } \\
\text { 4. Providing bank loan facilities (65) } \\
\text { Increase production and preservation of cattle feeds \& } \\
\text { fodder (60) } \\
\text { 6. Feeding UMS is beneficial (58) } \\
\text { 7. Preparation of balanced ration to reduce the cost (50) } \\
\text { Marketing aspect: } \\
\text { 1. Improvement of market facilities (96) } \\
\text { 2. Government legislation on market price (91) } \\
\text { 3. Price fluctuation should be checked (85) } \\
\text { 4. Proper capital management (80) }\end{array}$ \\
\hline
\end{tabular}

The management, factors, marketing system, problems and potential solutions of small scale cattle fattening in rural areas of Bangladesh are identified in this study. The results of this study will be useful to farmers and researchers to identify the overall problems and their remedies on feeding, management and marketing related to cattle fattening. So the findings may be act as a prescription of proper management of small scale cattle fattening in rural areas of Bangladesh.

\section{Literature Cited}

Ahmed, M., M. M. Hossain and S. Akhter. 2002. Cattle fattening as income generating activity by the farmers. Bang. J. Anim. Sci., 31 (1-2): 83-90.

Ali, M. A. and A. B. M. N. Anwar. 1987. Cattle Problem Confrontation in a Union of Mymensingh. Bangladesh J. Exten. Educ., 2(1): 41-49.

BBS (Bangladesh Bureau of Statistics). 2004. Statistical Pocket Book of Bangladesh. Statistics Division, Ministry of Planning, Government of the Peoples’ Republic of Bangladesh.

BBS (Bangladesh Bureau of Statistics). 2005. Statistical Pocket Book of Bangladesh. Statistics Division, Ministry of Planning, Government of the Peoples’ Republic of Bangladesh.

Begum, M. A. A., M. M. Hossain, M. Khan, M. M. Rahman and S. M. E. Rahman. 2007. Cattle Fattening Practices of Selected Farmers in Panchagarh District. Bang. J. Anim. Sci., 36(1\&2): 62-72.

FAO, 2004. Selected indicators of Food and Agriculture Development in Asia- pacific region, 19932003. Food and Agriculture Organization of the United Nations. Bangkok, Thailand. pp.119-121. 
Hashem, M. A., M. Moniruzzaman, S. Akhter and M. M. Hossain. 1999. Cattle fattening by rural farmers in different districts of Bangladesh. Bang. J. Anim. Sci., 28(1-2): 81-88.

Hossain, K. M., T. N. Nahar, A. I. Talukder and S. S. Kibria. 1996a. Beef fattening by rural women. In the proceeding of a national workshop on case studies "Success stories of women in Agriculture”. 27-28 August, 1995, BARC, Dhaka, Bangladesh.

Hossain, M. M. 1986. Study of cattle fattening program by landless and youth. Bang. J. Anim. Sci., 15 (1-2): 85-88.

Hossain, M. M., M. Saadullah and M. N. Miah. 2004. Effect of Urea Molasses Straw on Growth Performance of Cattle. Bang. J. Anim. Sci., 33(1-2): 67-77.

Hossain, M. S., M. M. Hossain, M. A. Hashem and R. N. Ali. 1996b. Transfer of feeding technology to promote cattle production of village level. Bang. J. Anim. Sci., 25(1-2): 51-56.

Hossain, S. 2002. Socio-economic upliftment of rural poor through cattle fattening. M. S. Thesis, Department of Animal Science, BAU, Mymensingh, Bangladesh.

Huq, M. A., M. M. H. Mondal, R. V. Collard and M. A. Huq. 1997. Integrated Farming Development project in Bangladesh. First Annual Report (1995-96). pp. 18-19.

Rahman, M. M., S. Akhter and M. M. Hossain. 1998. The availability of livestock feeds and feeding practices followed by the farmers of some areas of Mymensingh district. Bang. J. Anim. Sci., 27(1-2): 119-126.

Rahman, M.A., M. M. Hossain, M.A.K. Azad and S. Akhter. 2009. Factors affecting beef cattle production from farmers to consumers. Bangladesh J. Environ. Sci., 17: 182-187.

Rahman, S. M. E., M. M. Hossain, S. Majumder and M. A. Samad. 2001. Cattle fattening with Urea Molasses Straw and its effect on intake, growth and digestibility. Bang. J. Anim. Sci., 30(1-2): 99-105.

Rashid, A. 1969. The Marketing of jute in Pakistan National and International Aspects, West Pakistan Agricultural University, Liayalpur.

Skunmun, P., C. Chantalakhana, R. Pungchai, T. Poondusit and P. Prucsasri. 2002. Comparative Feeding of Nale Dairy, Beef Cattle and Swamp Buffalo. 1. Economics of Beef Production. Asian-Aust. J. Anim. Sci., 15(6): 878-883. 